\title{
Improving Access to Justice in Kenya through Horizontal Application of the Bill of Rights and Judicial Review
}

\author{
Doris Matu*
}

\section{Abstract}

Article 20 of the Constitution of Kenya 2010 states that the Bill of Rights binds all state organs and all persons. However, the extent to which natural persons and private legal persons can be held liable for human rights violations has become an issue. The courts have differed and provided mixed directions as to liability for human rights violations by private persons. Under the previous constitutional era, only decisions of public entities could be reviewed through judicial review. This article is an attempt to illustrate, with the aid of case law, the increased possibility for access to justice by the litigant in constitutional rights matters post-2010. We move from the previous era where human rights could not generally be sought against private persons to one where there is an attitude of acceptance, albeit a very cautious one, where rights can now be sought against any private persons. Also, there is hope for justice and a better society in general, if private bodies'decisions can also be judicially reviewed. Private entities wield immense power over individuals and it is crucial to lift the veil of privacy and go to the root of the matter by evaluating their decision-making processes.

\section{Introduction}

Horizontal application of the Bill of Rights has been defined as the concept of constitutional law that determines the regulation of relations between private individuals. ${ }^{1}$ Companies and other non-governmental actors have the ca-

\footnotetext{
The author is a post-graduate student of Law at the Kenya School of Law.

Gardbaum S, 'The "Horizontal Effect” of Constitutional Rights' 102 (3) Michigan Law Review, 2003, 388; For a Hohfeldian analysis of the rights that accrue in private relations see, Collins $\mathrm{H}$, 'On the (in) compatibility of human rights discourse and private law' LSE Law, Society and Economy Working Papers 7/2012, 16-17 - <https://www.lse.ac.uk/collections/law/wps/WPS2012-07_Collins.pdf,
} 
pacity to violate human rights. Employers in particular, can racially discriminate or dismiss employees for statements deemed to be contrary to the views held by the employer thereby curtailing the employee's freedom of expression. ${ }^{2}$

The horizontal application of human rights may be either direct or indirect. ${ }^{3}$ The Bill of Rights is directly applied when it is invoked by a litigant against another private entity or private person. This invocation is aimed at showing the inconsistency between the Bill of Rights and the conduct in question in order to obtain a remedy given by the constitution for the violation of a fundamental human right. ${ }^{4}$ An instance of this direct application mode was the Irish Supreme Court's decision in Lovett v Grogan. ${ }^{5}$ In that case, the plaintiff was the holder of an occasional passenger licence in accordance with the Road Transport Act 1932, and he carried out his transport business between Dublin and County Clare. The defendant was the principal shareholder in one of the other defendant companies that carried out the same business, albeit without the required licence to carry out such business. The plaintiff instituted proceedings in the High Court seeking that an injunction be granted against the defendants for operating their business without a licence. The plaintiff claimed that this was against his constitutional right to earn a living. The trial judge ruled in favour of the plaintiff and granted an injunction. The defendants appealed to the Supreme Court. In dismissing the appeal, the Supreme Court held that on the evidence produced in court, the defendants' activities were an actual threat and interference to the plaintiff's constitutional right to earn his living by lawful means. The purpose of the Road Transport Act 1932, was not to protect the licensed operators from competition by their unlicensed counterparts but to ensure that the licensed operator could restrain a breach of his constitutional rights stemming from a disregard of the Act. ${ }^{6}$

Indirect application occurs when the Bill of Rights is not directly invoked but instead the values that form its basis are adhered to when interpreting, developing or applying any laws. If a private law obligation is owed to another

on 19 July 2016; Leigh I, 'Horizontal Rights, the Human Rights Act and Privacy: Lessons from the Commonwealth?’ 48 (1) The International and Comparative Law Quarterly, 1999, 60.

2 Tushnet M, 'The issue of state action/ horizontal effect in comparative constitutional law' 1(1) International Journal of Constitutional Law,2003, 79.

3 Lubano $\mathrm{CN}$, 'The application of fundamental rights to private relations in Kenya: Striking a balance between fundamental rights and the freedom of contract' Published LLM Thesis, University of Cape Town, Cape Town, 2013, 33.

4 Currie I and De Waal J, The New Constitutional \& Administrative Law, Volume 1- Constitutional Law, Juta \& Company, Cape Town, 2001, 325.

5 John Lovett t/ a Lovett Transport v Robert Grogan t/ a PS Travel and Others (1995)3 IR 132, Supreme Court of Ireland.

(1995) 3 IR 132, 133. 
private party, that obligation's content should be determined in tandem with the applicable fundamental rights as opposed to bringing a direct constitutional right infringement claim. ${ }^{7}$ The Bill of Rights does not trump ordinary law or generate its own remedies; it operates indirectly through the ordinary laws' furtherance of its values. ${ }^{8}$ Constitutional rights can only be indirectly applied to some extent to private actors. ${ }^{9}$

In Germany, for instance, the Federal Constitutional Court (FCC) in the Handelsvertreter case, ${ }^{10}$ declared a non-competition clause in a contract between an agent and his principal to be unconstitutional. ${ }^{11}$ This was despite the fact that the clause was in compliance with the German Commercial Code which had been codified by the legislature and whose objective was to reduce conflicts of interest. When the FCC overturned the decision of the German Supreme Court, it held that it was the duty of the courts to develop private law in order to protect constitutional rights where the legislator had seemingly failed. ${ }^{12}$

Similarly in the Parabolantenne case, ${ }^{13}$ the FCC obliged a landlord to allow a Turkish tenant to install an additional antenna in his premises in order to be able to receive Turkish television programmes. The private law courts had upheld the refusal of the landlord to permit such an installation on the basis of the contract concluded between the parties. The FCC however found this contract to be unconstitutional. The private law courts were found to have violated the tenant's constitutional right to freedom of information by upholding the refusal of the landlord to allow for the installation of the antenna by the tenant. ${ }^{14}$

In discussing the horizontal application of the Bill of Rights and access to justice in Kenya, this paper is divided into two broad sections. The first major section deals with the acceptance of the horizontal application model of human

Collins $\mathrm{H}$, 'On the (in) compatibility of human rights discourse and private law', 16.

8 Currie I and De Waal J, The New Constitutional \& Administrative Law, 321; See also Florczak-Wator M, 'Horizontal dimension of constitutional social rights' 9(5) International Journal of Social, Behavioural, Educational, Economic, Business and Industrial Engineering, 2015, 1357.

9 Gardbaum S, 'The "horizontal effect" of constitutional rights', 398.

10 BVerfG 7 February 1990, BVerfGE 81, 242.

11 This finding was made by the FCC on the ground that it was contrary to the agent's constitutional right to freedom of profession guaranteed by Article 12(1) of the German Basic Law. The clause stated that the agent was barred from working in any capacity for any competitor of the principal for two years after the termination of the contractual relationship, and in the event that the termination was brought about by culpable behaviour of the agent, he would not be entitled to any compensation.

12 Cherednychenko O, 'Fundamental rights and private law: A relationship of subordination or complementarity?' 3(2) Utrecht Law Review, 2007, 6-7.

13 BVerfG 9 February 1994, BVerfG 90, 27.

14 Guaranteed by Article 5 (1), German Basic Law. 
rights in Kenya and how this acceptance may have improved access to justice in the country. The second section will broadly cover judicial review and its impact on access to justice. The traditional common law judicial approach was restricted to the review of decisions of public organs. The author argues that constitutional judicial review, may be an avenue to improve access to justice in Kenya.

This article aims to answer the following questions:

i) What are the benefits that accrue from the horizontal application of rights generally, and specifically with regard to access to justice; what conditions have to be met before it is applied?

ii) Is common law judicial review still a tenable means of enhancing access to justice in light of the Constitution's transformative agenda?

iii) Can access to justice be promoted by constitutional judicial review?

Section I gives a summary of the arguments that have been given supporting and those resisting the application of the Bill of Rights between private persons. It then proceeds to give a review of how the courts of law in Kenya have handled the subject matter at hand. Before 2010, most courts subscribed to the vertical-application mode thereby holding that rights could only be enforced against the State. After the promulgation of the Constitution in 2010, it seemed that some of the officers of the court were still stuck in the old order. This section also explains how the courts have seemingly changed their tune and are now more accommodative of horizontal application albeit in cases where it is possible to do so. Further, this section gives a review of the conditions that have been considered before the courts impose liability to a private entity or person for violation of human rights. There is also an attempt to link the increased acceptance of the concept of horizontal application of the Bill of Rights with the concept of access to justice. This paper seeks to inquire whether horizontal application of the Bill of Rights can be an avenue towards increased access to justice by various litigants. This, however, depends on the ingenuity of the courts and of policy-makers in coming up with the substantive content of the Bill of Rights. A brief conclusion of this first section follows.

Section II is an illustration of the traditional common law doctrine of judicial review. It highlights the conditions that had to be met before any matter could be judicially reviewed in Kenya and the United Kingdom (UK) from where Kenya borrowed the common law system. The 2010 Constitution entrenched the concept of judicial review and this section will show how it varies from the doctrine previously used in Kenya. There will be an attempt to show the improvement of access to justice if private bodies' decisions can also be reviewed. 


\section{Horizontal Application in Kenya}

\section{i. General arguments for and against horizontal application}

A strong case has been made for the application of the Bill of Rights to various private relationships. Among the key arguments advanced for this new found focus is the acknowledgment that there have emerged new centres of power in addition to the state. The rise of various types of associations, political parties, trade unions and multinational corporations has now led to the need for an increased and more divergent view of the dimensions of the public sphere. ${ }^{15}$

To buttress this notion, Joel Barkan noted, and most aptly so, that in the increasingly global economy, there has been less manifestation of political authority; which has led to growing concerns that the doctrine of constitutionalism could not be an adequate check on political power if it only focuses on the roles of states. Moreover, it was noted that the private entities were just as capable as states of causing oppression. ${ }^{16}$ In the realm of socio-economic rights, this new found power of non-state actors has led to a growing concern about their actions what impact they can have on the enjoyment of these rights. ${ }^{17}$

Furthermore, most of the functions which were previously vested in the state are now exercised and controlled by big multinationals and this is prevalent in key areas of the economy such as: energy, telecommunications, transport, water and sanitation..$^{18}$ Participation by these global private enterprises in such key areas of the economy has been said to give them some of the power that the State has traditionally had. ${ }^{19}$ These multinationals have monopolised the industries they have ventured into and are increasingly dictating the working conditions of the employees in the countries where they are set up. ${ }^{20}$ While there are

15 Clapham A, Human Rights in the Private Sphere, Oxford University Press, Oxford (SLASLEC 2016) 1993, 137.

16 Bakan J, The Corporation: The Pathological Pursuit of Profit and Power, New York, Free Press, 2004.

17 Nolan A, 'Holding non-state actors to account for constitutional economic and social rights violations: Experiences and lessons from South Africa and Ireland' 12(1) International Journal of Constitutional Law, 2014, 62.

18 Nandakumar SM, 'The shortcomings of corporate ethics and corporate social responsibility in the protection of human rights' 1(2) International Journal of Research and Analysis, 2013, 454.

19 Mensch N, 'Codes, lawsuits or international law: How should the multinational corporation be regulated with respect to human rights?' 14(2) University of Miami International and Comparative Law Review, 2006, 249.

20 Sethi SP, 'Corporate codes of conduct and the success of globalization' in Kuper A (ed), Global responsibilities: Who must deliver on buman rights?, Taylor and Francis Group, New York, 2005, 207 as cited in Mensch N, 'Codes, lawsuits or international law: How should the multinational corporation be regulated with respect to human rights?', 249 . 
benefits that accrue from the privatisation of such key sectors, this may effectively mean that natural resources and other core societal needs are controlled by private entities; over which the government may not have the desired control in order to hold them accountable for the proper treatment of their customers according to the municipal laws. ${ }^{21}$

Even though there are sound arguments for the imposition of liability on private enterprises for human rights violations, there are counter-arguments to support the point that these private entities should not have any liability imposed on them. Some of these arguments include the fact that these private enterprises are in business and the main reason for their existence is to make profit and promote the interests of their respective shareholders. ${ }^{22}$ Additionally, it has been stated that the only obligation that these private enterprises have is to obey the law and not to go out of their way to protect human rights. ${ }^{23}$ Vernon argues that the morally conscious companies disadvantage themselves competitively by spending the time and effort it takes to observe human rights, while their less scrupulous counterparts do not even bother to comply with human rights standards. $^{24}$

Another difficulty that has been recognised is the fact that the horizontal application of the Bill of Rights will almost certainly lead to the very difficult process of balancing competing fundamental rights which is made even more challenging by the lack of legislative guidance on the way to balance between the rights of the various private individuals or entities usually involved. ${ }^{25}$ An example of this very difficult balance in Kenya has been illustrated ${ }^{26}$ in situations of informal settlements in privately owned land where the owner is guaranteed of

21 Murphy SD, 'Taking multinational corporate codes of conduct to the next level' Conference on corporate governance and accountability in Sub-Saharan Africa, The Africa Project of the Institute for International Corporate Governance and Accountability at the George Washington University Law School, Washington, 29 October 2004, 9-10.

22 Friedman M, 'The social responsibility of business is to increase its profits' The New York Times Magazine, 13 September 1970 - <http://www.colorado.edu/studentgroups/libertarians/issues/ friedman-soc-resp-business.html > on 8 December 2016.

23. Muchlinski P, 'Human rights and multinationals: Is there a problem?' 77(1) International Affairs, 2001, 35.

24 Vernon R, 'Business and Human Rights' Harvard Law School Human Rights Program, 1999, 49 http://hrp.law.harvard.edu/wp-content/uploads/2013/08/BusinessandHumanRights.pdf on 29 June 2016; Lindenbergh SD, 'Fundamental rights in private law: Anchors or goals in a globalizing legal order?' Rotterdam Institute of Private Law Accepted Paper Series, 2010, 13.

25 Gerstenberg O, 'Private law and the new European constitutional settlement' 10(6) European Law Journal, 2004, 769.

26 See Matu D, 'Walking the tight rope - balancing property rights of individuals and the right to housing of informal settlers' 1(2) Strathmore Law Review, 2016, 95-118. 
the right to property ${ }^{27}$ while the right to housing ${ }^{28}$ is also stated under the Bill of Rights.

Private individuals or entities may be considered as parties in an equal position as compared to the difference in power between the State and an individual. This was stated as a reason why there was no need to have constitutional law permeate the realm of private law and it was only necessary where there was a need to control the State as an authority 'superior' to the individual. ${ }^{29}$ This is a rather untrue statement in these modern times due to the differences in economic power even between private individuals themselves. ${ }^{30}$

Gerstenberg has summarised the effects of extending fundamental rights between and among private (non-state) actors. He states that by holding private actors to standards that are also applied to public bodies threatens the autonomy of the private parties involved. Additionally, the judiciary effectively usurps the legislative powers by being the adjudicator in private law matters thereby overriding policy objectives of legislative regulation. Finally, this extension to private persons shifts authority from commercial or civil law courts to constitutional courts rendering private law redundant and superfluous. This negates the benefits of private law which is an area understood as a repository of evolving shared values and as a shorthand for a relatively insulated (against political conflict), free standing (with regard to moral diversity), insistently analogical, and incremental method of reasoning and of doctrinal accretion that avoids abstractions and socially divisive conflicts between first-order principles. ${ }^{31}$

If human rights are to be wholesome and properly applied, the law itself ought to be equally dynamic to cater for violations that are not directly propagated by the State. ${ }^{32}$ While both sides make a case for their viewpoints, it still cannot be forgotten that businesses do not exist in a vacuum and still, private individuals do not make business deals or other decisions in the abstract.

Article 40, Constitution of Kenya (2010).

Article 43(1)(b), Constitution of Kenya (2010).

29 Cherednychenko O, 'Fundamental rights, contract law and the protection of the weaker party: A comparative analysis of the constitutionalisation of contract law, with emphasis on risky financial transactions' Published PhD Thesis, G.J. Wiarda Institute, Utrecht University Institute for Legal Studies, Utrecht, 2007, 59.

30 Chirwa DM, 'In search of philosophical justifications and suitable models for the horizontal application of human rights' 8 African Human Rights Law Journal, 2008, 298.

31 Gerstenberg O, 'Private law and the new European constitutional settlement', 769.

32 Ratner S, 'Corporations and human rights: A theory of legal responsibility' 111 (3) Yale Law Journal, 2001, 472. 
They exist within the society where other individuals are undeniably affected by the decisions they make. ${ }^{33}$

\section{ii. $\quad$ The experience in Kenyan courts}

\section{a. Before 2010}

Under the Repealed Constitution, the extent to which the Bill of Rights could be applied in private disputes was not stated expressly or otherwise. This constitution was rather limited in its application and scope. It limited those it protected, the rights that were protected and those who were bound by the rights contained therein. ${ }^{34}$ The truth of these remarks was revealed in some of the decisions made by the judiciary where the judges, generally, limited the scope of the application of the rights to the relationships between individuals and the state and this was not extended to private relationships, at least not for a long time.

Nyamu J in the leading case of Kenya Bus Services Limited \& 2 others v Attorney General \& 2 others stated:

'Moreover fundamental rights and freedoms are contained in the Constitution and are principally available against the State because the Constitution's function is to define what constitutes Government and it regulates the relationship between the Government and the governed. On the other hand, the rights of individual interests are taken care of in the province of private law and are invariably redressed as such. ${ }^{35}$

Nyamu J in reaching his judgment in the Kenya Bus Services Limited case accepted the reasoning of the court in the case of Teitiwnnang $v$ Ariong \& Others, ${ }^{36}$ where the judge had ruled as follows:

'Dealing now with the question whether a private individual can maintain an action for declaration against another private individual on individual or individuals for breach of the fundamental rights provisions of the Constitution, the rights and duties of individuals and between individuals are regulated by private law. The Constitution on the other hand is an instrument of Government. It contains rules about the Government of the country. It is my view therefore that the duties imposed by the Constitution under the fundamental rights provisions are owed by the Government of the day to the governed. I am of the opinion that an individual or a group of individuals, as in this case, cannot owe a duty under the

33 Letza S, Sun X and Kirkbride J, 'Shareholding versus stakeholding: A critical review of corporate governance' 12 (3) Corporate Governance: An International Review, 2004, 250.

34 Constitution of Kenya Review Commission, The peoples' choice: Report of the Constitution of Kenya Revien Commission, 2002, 35.

35 (2005) eKLR.

36 Teitivnnang $v$ Ariong \& Others (1987) Law Reports of the Commonwealth (Constitutional \& Administrative Law), Trinidad \& Tobago (emphasis added). 
fundamental rights provisions to another individual so as to give rise to an action against the individual or a group of individuals since no duty can be owed by an individual or group of individuals to another or individual under the fundamental rights provisions of the Constitution, no action for a declaration that there has been a breach of duty under the provision can be or be maintained in the case before me, and I so hold' [emphasis mine].

Similarly, in the Alphonse Mwangemi case, the petitioners brought a constitutional petition against the respondents to seek redress for alleged delays in payment of salaries and subsequent termination of employment contracts. Outright, the judge dismissed the petitioners' claim for a number of reasons including the fact that the claims were based on the petitioners' respective contracts of employment which were in the private sphere and had nothing to do with the public. The respondent, a company incorporated under the Companies Act, ${ }^{37}$ was found not to be liable for any violations of rights under the Repealed Constitution as it was not a guarantor of such rights. ${ }^{38}$

In Richard Nduati Kariuki v Leonald Nduati Kariuki \& Another, a case involving a dispute regarding the division of the property of a deceased person, the respondent had sought redress for an alleged violation of his constitutional rights by the first and second applicants who were his step-brother and the family company respectively. The first applicant is said to have deliberately hatched a plan designed at excluding the respondent from inheriting his deceased father's estate. The applicants defended their cause in the constitutional petition by stating that they were private citizens and hence could not be held liable for constitutional violations. ${ }^{39}$ The court agreed with the applicants' contentions on this point and ruled that the constitution, as drafted, only recognised vertical application and therefore the applicants could not be found to be liable. ${ }^{40}$

That notwithstanding, the judge in the Richard Nduati case ${ }^{41}$ went a step further and recognised that there was a need for a paradigm shift to cause an expansion in the interpretation of constitutional provisions to cater for private actors who were increasingly carrying out public functions and had increasingly

\footnotetext{
Cap 486, Laws of Kenya (Repealed).

Alphonse Mwangemi Munga \& 10 Others v African Safari Club Limited (2008) eKLR, 7.

Richard Nduati Kariuki v Leonald Nduati Kariuki \& Another (2006) eKLR, 5.

Richard Nduati Kariuki v Leonald Nduati Kariuki \& Another (2006) eKLR, 7.

${ }^{1}$ The judge who decided this case was Nyamu J who had previously decided the Kenya Bus Services Limited case and sensationally claimed that private entities should not be found liable for human rights violations. He seems to have had a change of heart, however modest, by providing that the courts could find liability between private parties if the circumstances of the case so allowed and that there was nothing stopping the courts from doing so.
} 
amassed powers to oppress others. ${ }^{42}$ The judge stated that the courts had no deterrence to refuse to horizontally apply the Constitution whenever the facts of the case called for it. ${ }^{43}$

\section{b. The post 2010 era}

The Constitution of Kenya, came into force upon its promulgation on 27 August 2010.44 This repealed the constitution that was in place before the effective date. ${ }^{45}$ The Constitution of Kenya 2010 is the paramount source of law in Kenya ${ }^{46}$ It binds all persons ${ }^{47}$ and all state organs ${ }^{48}$ and it renders all laws that are inconsistent with it to be null and void to the extent of the inconsistency. ${ }^{49}$ The Constitution further requires every person to respect, uphold and defend it. ${ }^{50}$

In Uburu Muigai Kenyatta v Nairobi Star Publications Limited, ${ }^{51}$ the court seemed to continue with the reasoning that had prevailed under the previous constitutional dispensation. The petitioner alleged violation of Articles $28^{52}$ and $33^{53}$ of the Constitution of Kenya 2010. It was alleged that the respondent had published a story in 'the Nairobi Star' that was defamatory. ${ }^{54}$ Lenaola J, in determining whether a constitutional petition could be lodged between private persons, relied on the Kenya Bus Service case (Nyamu J) and held that constitutional obligations were not placed on individuals and that private law is the only realm that could handle complaints between individual persons. ${ }^{55}$ He quoted Article 21 of the Constitution which states that it is the obligation of the State and every State

42 Richard Nduati Kariukiv Leonald Nduati Kariuki \& Another (2006) eKLR, 8; Balkan J, 'The Corporation: The Pathological Pursuit of Profit and Power' New York, Free Press 2004.

43 Richard Nduati Kariuki v Leonald Nduati Kariuki \& Another (2006) eKLR, 11.

44 Article 263, Constitution of Kenya(2010).

45 Article 264, Constitution of Kenya (2010).

46 Article 2, Constitution of Kenya (2010).

47 Ambani J and Mbondenyi K, 'A new era in human rights promotion and protection in Kenya? An analysis of the salient features of the 2010 Constitution's Bill of Rights' in Mbondenyi K, Asaala $\mathrm{E}, \mathrm{Kabau} \mathrm{T}$ and Warris A (eds) Human rights and democratic governance in Kenya: A post-2007 appraisal, Pretoria University Law Press, 2015, 35-36. The writers recognise horizontal application as one of the salient features of the Constitution of Kenya 2010,

48 Article 2(1); 20(1), Constitution of Kenya (2010).

49 Article 2(4), Constitution of Kenya (2010).

50 Article 3(1), Constitution of Kenya (2010).

51 (2013) eKLR.

52 Every person has inherent dignity and the right to have that dignity respected and protected.

53 Sub-article 3 of this article states clearly that the freedom of expression has to be exercised in a manner that respects the rights and the reputations of others.

54 Uburu Muigai Kenyatta v Nairobi Star Publications Limited, (2013) eKLR, para. 3(a) - (g).

55 Uhuru Muigai Kenyatta v Nairobi Star Publications Limited, (2013) eKLR, paras. 9 - 11. 
organ to observe, protect, promote and fulfil the rights in the Bill of Rights. ${ }^{56}$ He also stated that this obligation to the state had, in no way, been extended to the individual and therefore he could not find the respondent liable for any violations. ${ }^{57}$

Gacheche J emphasised the need for Kenya to adopt a progressive stance and promote horizontal application of human rights according to the new realities adopted worldwide. She asserted that the view that human rights could only be vertically applied was a view that had long been overtaken by events. She stated thus:

'The rigid position that human rights apply vertically is being overtaken by the emerging trends in the development of human rights law and litigation [emphasis mine]. We can no longer afford to bury our heads in the sand, for we must appreciate the reality, which is that private individuals and bodies such as clubs and companies wield great power over the individual citizenry, who should as of necessity be protected from such non-State bodies who may for instance discriminate unfairly, or cause other Constitutional breaches... It must be clear by now that I find that the fundamental rights are applicable both vertically and horizontally, save that horizontal application would not apply as a rule but it would be an exception [emphasis mine], which would obviously demand that the courts examine the cases individually and decide them on a case-by-case basis'. ${ }^{58}$

The sentiments expressed in the Mwangi Stephen Mureithi High Court case (Gacheche J) cannot be referenced as law as the judgment was set aside by the Court of Appeal (Mwera, Musinga \& Ouko JJA). ${ }^{59}$ Efforts by the initial applicant to appeal to the Supreme Court were also quashed ${ }^{60}$ when the Court of Appeal (Nambuye, Gatembu \& M'Inoti JJA) held that the applicant had not adequately discharged his burden to show that the matter raised issues of general public importance in order to be considered as an appeal to the Supreme Court. ${ }^{61}$ Nonetheless, the principles expressed therein remain instructive.

Article 21, Constitution of Kenya (2010).

Uburu Muigai Kenyatta v Nairobi Star Publications Limited, (2013) eKLR, para. 12.

Mwangi Stephen Mureithi v Daniel Toroitich Arap Moi (2011) eKLR, 17-18.

9 Daniel Toroitich Arap Moi v Mwangi Stephen Muriithi \& Another, Civil Appeal No 240 of 2011 (2014) eKLR.

60 Mwangi Stephen Muriithi v Daniel Toroitich Arap Moi \& Another, Civil Application No Sup 10 of 2014 (UR 7/2014) (2014) eKLR.

61 Article 163 (4)(b), Constitution of Kenya (2010), Mwangi Stephen Muriithi v Daniel Toroitich Arap Moi \& Another, (2014) eKLR, 11-12. The applicant is said not to have discharged the burden required for the issuance of a certificate pursuant to Article 163 (5) of the Constitution of Kenyain order to obtain leave to appeal to the Supreme Court. 
In Stephen Saitoti Kapaikuv Cocacola Sabco Nairobi Bottlers Limited \& Another, ${ }^{62}$ the petitioner brought a claim in the High Court at Nairobi alleging the infringement of his constitutional right ${ }^{63}$ as a result of the consumption of a bottle of soda manufactured by the respondent which subsequently made him ill. The respondents opposed the petition stating that private individuals were not allowed by the Constitution to implement it, that this was strictly within the purview of the State. The court in this case held that whether or not a claim can be made by an individual against another individual or a company depended on the nature of the right. Ngugi J noted that although this matter touched on a part of the Constitution, it was primarily a claim under tort and could thus not be dealt with as a constitutional petition. ${ }^{64}$ Hence, in yet another instance, a private entity was not found to be constitutionally liable yet the court was keen to accept the fact that private persons could indeed be liable for violations of the fundamental rights and freedoms of other individuals.

Similarly, in Rose Wangui Mambo \& 2 Others v Limuru Country Club \& 17 Others, ${ }^{65}$ the petitioners had been barred from voting after a majority of the Board of Directors (respondents) passed a by-law that essentially served to prevent the female golfers of the club from voting at the upcoming general meeting where a new golf captain and a new golf vice-captain were to be elected. The by-law prevented female members from voting and only allowed them to attend the meeting as guests. This, according to the petitioners, was a violation of the constitutional right of freedom from discrimination. ${ }^{66}$ The respondents contested the petition on various grounds including the fact that Limuru Country Club was a private entity and was to be governed by its own rules and to be exempted from constitutional liability due to its private status. The court (Lenaola, Ngugi \& Majanja JJ) in dismissing this line of reasoning stated as follows:

'... It cannot be safe, in a progressive democratic society, to arrive at a finding that allows private entities to hide behind the cloak of 'privacy' to escape constitutional accountability [emphasis mine]. We think that it would be to accord a narrow, constricted interpretation to our Supreme Law, contrary to the canons of constitutional interpretation that have for ages infused our judicial system and which now find constitutional sanction under Article 259 to accede to such a proposition.

62 Petition No. 338 of 2012.

63 The petitioner claimed that his rights under article 46 of the Constitution of Kenya had been infringed. Article 46 enumerates various consumer rights such as the right to compensation for an injury caused by goods or services, protection of health and the right to goods of reasonable quality.

${ }^{64}$ Stephen Saitoti Kapaiku v Cocacola Sabco Nairobi Bottlers Limited \& Another,Petition No. 338 of 2012, paras. $12,15$.

65 (2014) eKLR.

${ }_{66}$ Article 27, Constitution of Kenya (2010). 
To accede to the respondents' proposition that private entities are insulated from the constitutional duty to respect and uphold fundamental rights, to hold that private entities are completely shrouded by their private cloak from this Court's scrutiny is, we believe, to reverse the intention of the framers of the Constitution. It is to strip individual Kenyans of the very constitutional protection that the Constitution of Kenya 2010 meant to jealously guard and leave them exposed and vulnerable in private dealings [emphasis mine]. This would effectively render the constitutional protections to be of little or no practical value to the very persons designed to enjoy its protections and would, in our view, amount to abdication of this Court's primary responsibility conferred upon it by the people of Kenyaa. ${ }^{67}$

Similarly, Majanja J in Isaac Ngugi v Nairobi Hospital \& 3 Others ${ }^{68}$ stated that he was hesitant to adopt a position that would serve to act as an impediment to the intended transformative power of the Constitution through the application of the Bill of Rights to private relationships. ${ }^{69}$

The court acknowledged that matters which had previously been decided regarding the issue of the application of the Bill of Rights to private relationships and the extension of liability beyond the State and its organs had been misunderstood and misinterpreted and that this resulted in the impression that the Bill of Rights could only be enforced against the State. ${ }^{70}$

\section{iii. Conditions for the horizontal application of the Bill of Rights}

For a claim for the violation of the fundamental rights and freedoms to be brought against an individual, the nature of the right must be considered. ${ }^{71} \mathrm{It}$ has been argued that the horizontal application of the Bill of Rights cannot be decided in the abstract and a theoretical deduction cannot be solely employed to determine the appropriateness of such an application. ${ }^{72}$ There has to be an evaluation of the context within which the horizontal application is sought, and especially the situation of the private party against whom the right is sought. ${ }^{73}$

67 Rose Wangui Mambo \& 2 Others v Limuru Country Club \& 17 Others (2014), paras 68-69 (emphasis added).

68 (2013) eKLR.

69 Isaac Ngugi v Nairobi Hospital \& 3 Others,Petition No 407 of 2012 (2013) eKLR, para 25.

70 Satrose Ayuma \& 11 Others $v$ Registered Trustees of the Kenya Railways Staff Retirement Benefits Scheme \& 3 Others, Petition No. 65 of 2010 (2013) eKLR, para 55.

71 Stephen Saitoti Kapaiku v Cocacola Sabco Nairobi Bottlers Limited \& Another, paras 12-13, 14.

72 Currie I and Waal J, The Bill of Rights Handbook, 53 as cited in Lubano CN, 'The application of fundamental rights to private relations in Kenya: Striking a balance between fundamental rights and the freedom of contract', 39.

73 Liebenberg S, Socio-Economic Rights: Adjudication under a Transformative Constitution, 1ed, Juta \& Company, Claremont, 2010, 322. 
Additionally, it has been noted, and rightly so, that not all persons have equal capacity to comply with the various obligations that arise from the application of rights. ${ }^{74}$

In relation to the horizontal application of socio-economic rights, Ellmann argues that the extent to which a private entity is to be held liable for violation of these rights depends on the nature and extent of the power exercised by the entity, the degree to which the power emulates state powers and the impact of the power on the enjoyment of socio-economic rights. ${ }^{75}$

Bhana argues that the acceptance of the application of the Bill of Rights to private persons cannot mean that public bodies, private entities and persons are to be treated in the same way in terms of the liability accruing to them respectively in matters of the enforcement of fundamental rights. Individuals are also not to be treated alike. He advocates for a mode of treatment that differentiates the treatment given to public and private bodies, and even between private individuals amongst themselves. He advocates for the consideration of factors such as: the parties' station in life, which may possibly include their financial and economic welfare; the likelihood of the promotion of freedom, dignity and equality in light of the facts in question; and finally, the nature of the relevant constitutional rights arising in a particular case and the corresponding duties that may arise. ${ }^{76}$

In addition to taking cognisance of the nature of the right that the plaintiff or claimant in a successful constitutional petition may be entitled to, it is critical that there is a proper appraisal of the nature of the duty that would arise on the private party who is found to be so liable. It is crucial that there is a determination of the suitability of the enforcement of that right to this private respondent. The conduct of private parties relies on private funds and it should not therefore be held to the same standards as public organs which are publicly funded. ${ }^{77}$

74 Pieterse M, 'Indirect horizontal application of the right to have access to health care services' 23 South African journal of human rights, 2007, 161.

75 Ellmann S, "A constitutional confluence: American "State-action" law and the application of South Africa's socio-economic rights guarantees to private actors' in Andrews P and Ellmann S (eds) The post-apartheid constitutions: Perspectives on South Africa's basic law, 1" ed, Ohio University Press, 2001, 444, 446, $462-467$.

76 Williams L, "The legal construction of poverty: Gender, "work" and the "social contract" 22Stellenbosch Law Review, 2011, 463, 468-473; 478-481 as cited in Bhana D, 'Constitutionalising contract law: Ideology, judicial method and contractual autonomy', 32.

77 Currie I and De Waal J, The new constitutional \& administrative law, 324; Cheadle H, Davis D and Haysom N, South African constitutional law: The bill of rights, $2^{\text {nd }}$ ed, Butterworths, Durban, 2005, 3-18. 
Nolan has argued that the courts should be more willing to adopt a horizontal application model where the fundamental rights in question are absolutely indispensable to the survival and dignity of the rights holder. ${ }^{78}$ While this may seem very appealing in trying to assure justice to those persons whose rights have been violated, it is the author's view that this would only be achieved by a painstaking process of establishing the absolute necessity of a particular right to the survival of the applicant. Nevertheless, it ought to be under consideration by the courts.

The courts in Kenya have been quite pragmatic in addressing this issue. In the Rose Wangui Mambo case, for instance, the court remarked that horizontal application was not an open cheque and consequently, it had to place a caveat on its application by analysing the individual circumstances of each case. ${ }^{79}$ In the Isaac Ngugi case, the court held that the issue of horizontal application of the Bill of Rights was now without a doubt, and the only issue was the extent to which these rights were to apply to private relationships. The judge stated as follows:

'Horizontal application or enforcement against the State depends on the nature of the right and fundamental freedom and the circumstances of the case... The court would be reluctant to apply the Constitution horizontally where specific legislation exists to regulate the private relations in question'. ${ }^{80}$

The court may proceed to directly apply the provisions of the Constitution where the mechanisms provided to effectuate the constitutional guarantee are inadequate even though there exists private law regulating the matter within the scope of application of the constitutional right or fundamental freedoms. ${ }^{81}$

All in all, as the courts grapple with the application of constitutional rights in private law regimes, there is need for the courts to be cautious and acutely aware of the practical effects that a finding of constitutional rights violation would mean for the litigants. Would it be so unsuitable or ill-fitted due to the defendant's indigence? Would it be one that would cause a rather heavy and unjust burden on the litigants? Are there other suitable remedies in private law? These are some of the questions to be considered in order to give orders and judgments that promote access to justice for litigants in Kenya.

\footnotetext{
78 Nolan A, 'Holding non-state actors to account for constitutional economic and social rights violations: Experiences and lessons from South Africa and Ireland', 90.

79 Rose Wangui Mambo \& 2 Others v Limuru Country Club \& 17 Others, (2014) eKLR, para 72.

80 Petition No 407 of 2012 (2013) eKLR, paras 22-23 (emphasis added).

81 Petition No 407 of 2012 (2013) eKLR, para 23.
} 


\section{iv. Enhancing access to Justice through the horizontal application of the Bill of Rights}

Access to justice is a concept that has been described as the judicial and administrative remedies and procedures available to a person (natural or juristic) aggrieved or likely to be aggrieved by an issue. It refers also to a fair and equitable legal framework that protects human rights and ensures delivery of justice. ${ }^{82}$

Lord Woolf identified certain key ingredients that a justice system has to meet in order to facilitate access to justice by the users of the system. The system should be just in the results it delivers: be fair in the way it treats litigants; offer appropriate procedures at a reasonable cost, deal with cases with reasonable speed, be understandable to those who use it, be responsive to the needs of those who use it; provide as much certainty as the nature of particular cases allow and be effective and adequately resourced and organised. ${ }^{83}$

These have, in one way or another, been codified in the Constitution of Kenya 2010 which requires that justice is done to all, regardless of status. ${ }^{84}$ Furthermore, the Constitution is to be interpreted in a manner that promotes its purposes, values and principles and advances the rule of law, human rights and fundamental freedoms in the Bill of Rights. ${ }^{85}$ Access to justice requires also that reasonable fees are charged to litigants and that these costs are not to be an impediment to access to justice. ${ }^{86}$ In applying the Bill of Rights in Kenya, a court is required to develop the law to the extent that it does not give effect to a certain right or freedom. Courts are also mandated to adopt an interpretation of the Bill of Rights that most favours the enforcement of the rights therein. ${ }^{87}$

With regard to the matter at hand on the horizontal application of fundamental rights, it is important that even the litigants who institute a claim against another individual or private entity are assured of justice in the event that a claim is successful and a violation of any rights is found to have been committed. It should not be the case that a litigant is denied justice based on the fact that the

82 Ladan MT, 'Access to justice as a human right under the ECOWAS community law' The Commonwealth Regional Conference on the $21^{\text {st }}$ century lawyer: Present challenges and future skills, Abuja, 8-11 April 2010, 3.

83 Lord Woolf, MR, Final Report to the Lord Chancellor on the civil justice system in England and Wales, July 1996 - http://webarchive.nationalarchives.gov.uk/+/http://www.dca.gov.uk/civil/final/overview. htm on 26 July 2016.

${ }^{84}$ Article 159 (2)(a), Constitution of Kenya (2010).

85 Article 259, Constitution of Kenya (2010).

86 Article 48, Constitution of Kenya (2010).

87 Article 20 (3), Constitution of Kenya (2010). 
defendant is a private body. This is attributed to the long-standing tradition that it is the State that has the duty to protect rights of its citizens. While it is indeed true that the State has a major role in protecting and promoting fundamental rights and freedoms, the judiciary must remain alive to the situation in the current constitutional dispensation that now requires every person to respect, uphold and defend the Constitution. ${ }^{88}$

Moreover, the contemporary world has seen even its private members perpetuate all kinds of violations against others.

Access to justice in Kenya can be said to have been achieved by the mode of horizontal application to the extent that now, the range of persons who can be found liable for constitutional rights violations includes private individuals, corporate bodies and other associations that are non-governmental. No longer are litigants (as shown in section IV of this paper) sent away from the courts by the mere fact that they have brought a petition against a private entity or a private individual. This is a departure from the previous practice where rights were enforced against the State only. Access to justice may, however, be impeded if there are no significant developments in the content of the rights that are so often pitted against each other in a constitutional rights' violation contest. It is fundamental that the courts come up with consistent ways of balancing these rights. Otherwise, all will come to naught in the quest to promote human rights and prevent violations by private members or bodies.

\section{v. Conclusion}

The Constitution of Kenya 2010 brought with it radical changes to the human rights landscape. Among the numerous changes was the express intimation of the fact that all persons were to be bound by the provisions of the Constitution. This undoubtedly means that private bodies and individuals could no longer continue with the violation of the fundamental rights of other citizens unchecked. They can no longer hide behind the cloak of privacy or autonomy. The courts have now been given the power to find them liable for the violations and litigants may now bring such matters to the attention of the courts.

Within this same Constitution, we are all enjoined to promote its values. These values include: human dignity, equality and social justice. It is in light of these values that the horizontal mode of application ought to be embraced even

88 Article 3(1), Constitution of Kenya (2010). 
further; to come to par with the current economic and social situations in our country where private individuals are increasingly capable of harming other individuals and preventing the enjoyment of their rights as listed in the Bill of Rights. The courts and all branches of government are to work tirelessly to make the aspirations of the Kenyan people as inscribed in the preamble of the Constitution a reality in order to move forward towards a better society.

\section{Judicial Review and Access to Justice}

The purpose of this section is to briefly review the development of the concept of judicial review from the common law approach used in Kenya to what has now been enshrined in the Constitution and the consequent legal implications. In Section I of this paper, horizontal application of the Bill of Rights has been examined and it has been illustrated that the concept has gained some acceptance in Kenya's legal landscape. This section seeks to illustrate that even though judicial review is still principally allowed only against decisions of public bodies, there is hope for increased access to justice through the expansion of the grounds for judicial review applications; and if there is a more proactive approach to the examination of the parties against whom such orders are sought as opposed to the immediate collapse of an application due to it being brought against a private organisation. This is in the backdrop of the contemporary world where private organisations also make decisions which substantially affect people's rights and freedoms.

\section{i. The common law judicial review}

This is the form of judicial review that was in use in Kenya before judicial review was entrenched in the 2010 Constitution. In the Anisminic case, ${ }^{89}$ Lord Reid held that the purview of judicial review was not to consider whether the decision that had been made by the decision-maker (Foreign Compensation Commission) was wrong and hence review the merits of that decision. His only duty was to concern himself with the question of whether the Commission had considered anything that it should not have considered. Judicial review only looks to the process of decision making. The merits or substance of a case may be reviewed through appeals.

Anisminic Limited v Foreign Compensation Commission (1969) 2 AC 147. 
Lord Diplock, speaking in the Council of Civil Service Unions case, ${ }^{90}$ gave an important speech on judicial review. He discussed judicial review on three fronts. These were: first, persons against whom judicial review could lie. Second, decisions against which judicial review could lie. Lastly, the grounds of judicial review were also elaborated on. Of persons against whom judicial review could arise, he said that judicial review could be brought against a decision maker who had made or refused to make a certain decision. The decision maker had to derive his power from public law and not from a private law agreement. The source of this power could be a statute or a subsidiary legislation or the common law itself. ${ }^{91}$

The view taken by the decision-maker had to have an effect on another person other than the decision maker although it could affect him as well. This effect could be in the form of denying him certain rights or benefits that he was previously entitled to and which he had legitimately expected to continue enjoying or receiving. For this denial to be valid, it had to be communicated to the beneficiary or recipient with a degree of rationality for such denial. A denial of a benefit or right could not be withdrawn without giving the beneficiary the right to be heard in contestation of this denial if there had been a previous assurance from the decision maker that the benefit would not be withdrawn without first hearing the beneficiary. The decision also had to alter the rights or obligations of a person which were enforceable by or against him in a private law matter. ${ }^{92}$

The grounds for judicial review that emanated from this case were: illegality, irrationality and procedural impropriety. ${ }^{93}$ The principle of legality requires that the decision making body must understand correctly and apply the power according to the law giving this power. He must not act in any way that is illegal by standards of the applicable laws. Irrationality requires that the decision taken has to be within the bounds of logic and morally accepted standards and if a reasonable person would have tasked to decide, he would have arrived at a similar decision. Procedural impropriety occurs when the decision maker fails to observe any procedural rules that have been laid down for the exercise of the power vested in that body. It also includes the failure to observe the basic rules of natural justice and fairness. ${ }^{94}$

\footnotetext{
Council of Civil Service Unions v Minister for the Civil Service (1985) AC 374.

Council of Civil Service Unions case, 408-409.

Council of Civil Service Unions case, 408.

Council of Civil Service Unions case, 410.

Council of Civil Service Unions case, 411.
} 
Traditionally in Kenya, orders for judicial review were to be granted if there existed the three grounds, that is, illegality, irrationality and procedural impropriety. However, in Republic v The Commissioner of Lands Ex parte Lake Flowers Limited, ${ }^{95}$ the court stated as follows:

'Although judicial review has been bequeathed to us with defined interventions namely: illegality, irrationality and impropriety of procedure, the intervention has been extended using the principle of proportionality... The court will be called upon to intervene in situations where authorities and persons act in bad faith, abuse power, fail to take into account relevant considerations in the decision making or take into account irrelevant considerations or act contrary to legitimate expectations... Even on the important principle of establisbing standing for the purposes of judicial review the Courts must resist being rigidly chained to the past defined situations of standing and look at the nature of the matter before them... [emphasis mine]. Judicial review is a tool of justice, which can be made to serve the needs of a growing society on a case-to-case basis... The court envisions a future growth of judicial review in the human rights arena where it is becoming crystal clear that human rights will evolve and grow with the society'. ${ }^{96}$

In Kenya, applications for judicial review were allowed only if the decision being challenged was that of a public body. In Mureithi \& 2 Others v AG \& 5 Others, ${ }^{97}$ Nyamu J held that the remedies of mandamus, prohibition or certiorari were only available against public bodies. ${ }^{98}$

Wendoh $\mathrm{J}^{99}$ considering the possibility of reviewing a decision made by the Kenya Crickets Association and the International Cricket Council to ban Maurice Odumbe from playing cricket for five years found that the matter had been determined by a private arbitration and hence could not be subject to judicial review. ${ }^{100}$ Moreover, the judge noted that, by the Kenya Crickets Association giving the applicant a five year ban, there was no public element involved; only a private right which could not be challenged in Judicial Review. ${ }^{101}$ Migai Akech criticised this decision for the apparent failure by the court to recognise that the publicprivate distinction had started to become untenable due to the immense power that exists within private entities and it would be inappropriate to assume that in the private sphere the power between all the parties was the same. ${ }^{102}$

\footnotetext{
95 Nairobi High Court Miscellaneous Application No. 1235 of 1998.

96 Republic v The Commissioner of Lands Ex parte Lake Flowers Limited.

97 Mureithi \& 2 Others (For Mbariya Murathimi Clan) v Attorney General \& 5 Others, Nairobi HCMCA No. 158 of 2005.

98 Mureithi \& 2 Others $v$ AG \& 5 Others.

99 Republic (through Maurice Omondi Odumbe) v Kenya Cricket Association \& 2 Others (2006) eKLR.

100 Maurice Odumbe case, 6.

101 Maurice Odumbe case, 3.

102 Akech M, 'The Maurice Odumbe investigation and judicial review of the power of International Sports Organizations' 6(2) Entertainment and Sports Law Journal, 2008, para 72.
} 
In Kuria \& 3 Others $v$ Attorney General, ${ }^{103}$ the Court expressed itself as follows:

'So long as the orders by way of judicial review remain the only legally practicable remedies for the control of administrative decisions, and in view of the changing concepts of good governance which demand transparency by any body of persons having legal authority to determine questions affecting the rights of subjects under the obligation for such a body to act judicially, the limits of judicial review shall continue extending so as to meet the changing conditions and demands affecting administrative decisions... [emphasis mine]. This therefore implies that the limits of judicial review should not be curtailed, but rather should be nurtured and extended in order to meet the changing conditions and demands affecting the decision-making process in the contemporary society. The law must develop to cover similar or new situations and the application for judicial review should not be stifled by old decisions and concepts, but must be expansive, innovative and appropriate to cover new areas where they fit'. ${ }^{104}$

\section{ii. Judicial review under the 2010 constitutional dispensation}

The Constitution allows for the grant of an order for judicial review in the event that a person's right or fundamental freedom in the Bill of Rights has been denied, violated or infringed, or is threatened. ${ }^{105}$ Additionally, every person has the right to administrative action that is expeditious, efficient, lawful, reasonable and procedurally fair. ${ }^{106}$ Parliament was mandated to enact legislation that would govern review of administration action by a court or an independent tribunal and promote its efficiency. ${ }^{107}$

The legislation enacted pursuant to this constitutional requirement was the Fair Administrative Action Act. ${ }^{108}$ The Fair Administrative Action Act applies to all state and non-state application agencies. It also includes any person exercising administrative authority; performing a judicial or quasi-judicial function under the Constitution or any written law; or whose action, omission or decision affects the legal rights or interests of any person to whom such action, omission or decision relates. ${ }^{109} \mathrm{It}$ is important to note that the Constitution describes a person to include a company, association or other body of persons whether incorporated or unincorporated. ${ }^{110}$ This promotes the

(2002) 2 KLR 69.

104 Kuria \& 3 Others v Attorney General.

105 Article 23(3) (f), Constitution of Kenya (2010).

106 Article 47, Constitution of Kenya (2010).

107 Article 47(3), Constitution of Kenya (2010).

108 Act No. 4 of 2015.

109 Section 3(1), Fair Administrative Action Act (Act No. 4 of 2015).

110 Article 260, Constitution of Kenya (2010). 
argument that the actions of a private entity can now be judicially reviewed. Further, all persons (State or non-State) are enjoined to respect, uphold and defend the Constitution ${ }^{111}$ and to promote the national values and principles of governance in the application or interpretation of the Constitution or any law. ${ }^{112}$ These principles include: human dignity, equity, social justice, inclusiveness, equality, human rights, nondiscrimination and transparency. ${ }^{113}$

Flowing from these legal provisions, it is imperative that any person who makes decisions that affect the rights of others has the mandate to ensure that the power they hold is exercised in line with the principles as outlined above and with the ultimate goal of furthering the values imbued in the Constitution.

\section{iii. Conclusion}

The acceptance of judicial review of private entities' decisions would cure a situation where private law remedies like an injunction, compensation or even an award for damages are not sufficient to correct the injustice or unfairness brought about by the process that was used to arrive at a certain decision. It is the author's argument that justice should not only be substantive but it must also be procedurally correct. We must not only strive towards getting compensation for a damage suffered but must also be willing to correct our institutions whenever they go wrong. The author believes that the role of taking care of our institutions and the legitimacy of the decisions they make can be reached through judicial review. Judicial review can enhance access to justice if it is also recognised that private entities' decisions substantially affect the rights of individuals. However, the autonomy of private organisations has to be balanced in the face of applications for review of decisions affecting the rights of other individuals.

\section{Conclusion}

To conclude this paper, the author is of the opinion that horizontal application of the Bill of Rights and judicial review are tools that can be utilised to enhance access to justice to victims of rights' violations or infringement if the Bill of Rights is horizontally applied and if the grounds for judicial review are expanded and the locus standi in such matters is not unduly restricted.

Article 3, Constitution of Kenya (2010).

Article 10, Constitution of Kenya(2010).

113 Article 10(2), Constitution of Kenya (2010). 